\title{
Church polity
}

and politics in the

British Atlantic world,

$$
\text { c. } 1635-66
$$

EDITED BY

ELLIOT VERNON AND HUNTER POWELL 
Church polity and politics in the British Atlantic world, c. $1635-66$

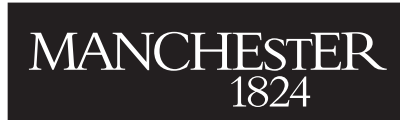

Manchester University Press 
Politics, culture and society in early modern Britain

\author{
General Editors \\ PROFESSOR ALASTAIR BELLANY \\ DR ALEXANDRA GAJDA \\ PROFESSOR PETER LAKE \\ PROFESSOR ANTHONY MILTON \\ PROFESSOR JASON PEACEY
}

This important series publishes monographs that take a fresh and challenging look at the interactions between politics, culture and society in Britain between 1500 and the mideighteenth century. It counteracts the fragmentation of current historiography through encouraging a variety of approaches which attempt to redefine the political, social and cultural worlds, and to explore their interconnection in a flexible and creative fashion. All the volumes in the series question and transcend traditional interdisciplinary boundaries, such as those between political history and literary studies, social history and divinity, urban history and anthropology. They thus contribute to a broader understanding of crucial developments in early modern Britain.

Recently published in the series

Chaplains in early modern England: Patronage, literature and religion

HUGH ADLINGTON, TOM LOCKWOOD AND GILLIAN WRIGHT (eds)

The Cooke sisters: Education, piety and patronage in early modern England GEMMA ALLEN

Black Bartholomew's Day DAVID J. APPLEBY

Insular Christianity ROBERT ARMSTRONG AND TADHG Ó HANNRACHAIN (eds)

Reading and politics in early modern England GEOFF BAKER

'No historie so meete' JAN BROADWAY

Writing the history of parliament in Tudor and early Stuart England PAUL CAVILL and ALEXANDRA GAJDA (eds)

Republican learning JUSTIN CHAMPION

News and rumour in Jacobean England: Information, court politics and diplomacy, 1618-25 DAVID COAST

This England PATRICK COLLINSON

Sir Robert Filmer (1588-1653) and the patriotic monarch CESARE CUTTICA Doubtful and dangerous: The question of succession in late Elizabethan England SUSAN DORAN AND PAULINA KEWES (eds)

Brave community JOHN GURNEY

'Black Tom' ANDREW HOPPER

Reformation without end: Religion, politics and the past in post-revolutionary England ROBERT G. INGRAM

Revolution remembered: Seditious memories after the British Civil Wars EDWARD JAMES LEGON

Royalists and Royalism during the Interregnum JASON MCELLIGOTT AND DAVID L. SMITH

Laudian and Royalist polemic in Stuart England ANTHONY MILTON

The crisis of British Protestantism: Church power in the Puritan Revolution, 1638-44 HUNTER POWELL

The gentlewoman's remembrance: Patriarchy, piety, and singlehood in early Stuart England ISAAC STEPHENS

Exploring Russia in the Elizabethan Commonwealth: The Muscovy Company and Giles Fletcher, the elder (1546-1611) FELICITY JANE STOUT

Loyalty, memory and public opinion in England, 1658-1727 EDWARD VALLANCE

Full details of the series are available at www.manchesteruniversitypress.co.uk. 


\title{
Church polity and politics in the British Atlantic world, c. 1635-66
}

\author{
EDITED BY ELLIOT VERNON AND \\ HUNTER POWELL
}

Manchester University Press 


\section{Copyright (C) Manchester University Press 2020}

While copyright in the volume as a whole is vested in Manchester University Press, copyright in individual chapters belongs to their respective authors, and no chapter may be reproduced wholly or in part without the express permission in writing of both author and publisher.

Published by Manchester University Press

Altrincham Street, Manchester Mi 7JA

www.manchesteruniversitypress.co.uk

British Library Cataloguing-in-Publication Data

A catalogue record for this book is available from the British Library

ISBN 978 o 7I90 90424 hardback

First published 2020

The publisher has no responsibility for the persistence or accuracy of URLs for any external or third-party internet websites referred to in this book, and does not guarantee that any content on such websites is, or will remain, accurate or appropriate.

Typeset in 10/12 Scala by

Servis Filmsetting Ltd, Stockport, Cheshire 